\title{
CRITICAL CONSIDERATIONS REGARDING THE LIMITS OF THE POWER TO REVISE THE ROMANIAN CONSTITUTION
}

DOI: $10.47743 /$ rdc-2018-1-0001

Dan Claudiu DĂNIȘOR ${ }^{1}$

\section{Abstract}

By starting from several principle considerations regarding the relations between the constituent power, the original and the derived constituent authority, I shall make a critical analysis of the limits of the power to revise the Constitution, such as they regulated in 1991 Constitution of Romania. The material limits of the revision raise certain problems in terms of necessity, clarity and, in the case of Republican form of government, of the validity of introduction into the legal system. The teleological limits which prohibit revisions that result in the suppression of fundamental rights and freedoms or their guarantees raise several definition problems, especially when the effect targeted by the constitutional interdiction is indirectly obtained. Finally, the limitation in exceptional situations betrays the lacunae of the Constitution of Romania in their definition, and in the case of the prohibition of revision in times of war, the contradictory historical experiences.

Keywords: limits of revision; constituent power; constituent authority; form of government; the guarantee of human rights; the substance of fundamental rights and freedoms

The constituent power is distinct from the constituent authority and the latter is in turn original and derived. An extremely important problem concerns the relations between the above mentioned. Is there a hierarchy of wills? Are the acts into which the will of the constituent power and the will of the constituent authority are transposed differently positioned in the normative hierarchy? What about the acts of the two forms of constituent authority?

The answer to the first question depends on way in which the manifestation of collective will is conceived. If the nation can only express itself through representation,

\footnotetext{
${ }^{1}$ Professor, PhD, University of Craiova, The Doctoral School of the Faculty of Law, The Romanian Academy of Legal Sciences, The Fundamental Legal Research Centre.
}

STUDIES AND ARTICLES 


\section{Dan Claudiu DĂNIŞOR}

there is no normative act in which the will of the constituent power of the nation or the people can be directly transposed. From this point of view, it is not a matter of the conformity of the acts of the constituent authority with the acts in which the will of the constituent power is directly manifested. There is no constituent power before the adoption of the Constitution. This is the manner in which the problem was conceived in the United States at the end of the $18^{\text {th }}$ century. Here is how Antonio Negri comments on this absorption of the constituent power by the constitutional machine: "The concept of people never identifies in America with the one of 'general will'. [...] The theoretical and practical essence of the American constituent power is, on the contrary, 'everybody's will': the idea of multiple representation and of a vast network of individual wills [...]. What stands out [...] is the true translatio of the constituent power which was achieved here. For the first time, it is no longer conceived as something that founds the constitution, but as the gas that fuels its engine. The constituent power is no longer an attribute of the people [...]; [...] it has become an arrangement of political society: the latter is the one that forms the people through representation, through all the gears of the constitutional machine. Homo politicus is redefined through the constitution. In the absence of the constitution there is no constituent power [...] The constituent power thus becomes an arrangement of the organised power; it is defined as being the capacity to form the government of the political society. [...] In the absence of the constitution, of the constitutional machine and the governmental organisation there is, therefore, no constituent power"2.

The American Republic is different from democracy. "Democracy is insufficient. [...] The American democracy is therefore made here Republican democracy. [...] 'The democracy and the Republic are different in [...] essential points: $1 /$ the delegation of the government in the Republic to a small number of citizens elected by the people [...']"' 3. "[...] Federalism plays the role of democratic counter-balance. [...] The compromise between national constitution and federalism is the compromise between republicanism and democracy"4.

From this perspective, it is not a matter of a limitation on the constituent authority imposed by the constituent power. If there are limits of the possibility of revision, they are imposed by the functional necessities of the governmental machine and by the territorial organisation of power, by federalism, not by any power which is external to these mechanisms. They are technical, not material. Thus, the American Constitution,

\footnotetext{
2 A. Negri, Le pouvoir constituant. Essai sur les alternatives de la modernité, P.U.F., Paris, 1997, pp. 214 - 218.

3 "Le Fédéraliste", no 10, p. 73. The quotes are from Le Fédéraliste (Commentaire de la Constitution des Etats-Unis) - Recueil d'articles écrits en faveur de la nouvelle Constitution telle qu'elle a été adoptée pa la Convention fédérale le 17 septembre 1787, par A. Hamilton, J. Jay et J. Madison, Nouvelle édition française avec une introduction bibliographique et historique par Gaston Jèze, avec une préface de A. Esmein, Paris, V. Giard \& E. Brière, 1902.
}

${ }^{4}$ A. Negri, op. cit., pp. 216-220.

CONSTITUTIONAL LAW REVIEW 


\section{Critical considerations regarding the limits of the power...}

"in as far as the organised method to introduce amendments is concerned, is neither entirely federal, nor entirely national" 5 .

During the debates concerning the 1991 Constitution of Romania, there was a tendency to embrace such a conception. At least indirectly, because some parliamentarians felt the movement towards the empowerment of the Constitution against the will of the constituent power. The apparent motif was the latter's vague character. Actually, the scope of imposing the Republic as form of government and the interdiction of its revision brought about the distinction. Here is Mr. Sorin-Mircea Bottez' reaction: "It was for this that they invented the referendum - otherwise the Constitution would have been sufficient" 6 .

The admission of the procedural forms of the direct manifestation of the people within the frame of direct government seems to resolve the problem, because the people seems to then manifest itself directly. Its direct will and the acts into which it is transposed are superior to those of the constituent, original or derived authority. Nevertheless, the electoral body itself can be conceived as an organ of the nation, if not even as one of the state, as an instituted power, therefore as form of representation of the constituent power. And, in this vision, the electoral body at a specific time, being only an instituted power, cannot materially limit the possibility of revision of certain constitutional provisions, due to the fact that it would limit the future electoral body, without such a limit being imposed by a legal principle superior to those which transpose the will of the diverse electoral bodies.

The only manner of conceiving the problem which would lead to the possibility of validly introducing material limits of the power of the revising authority is the one in which there is a type of law which is anterior and superior to state law, directly instituted by the unorganised collectivity. It is somewhat similar to what Léon Duguit was saying: "if the fundament of the law outside its creation through the state cannot be established, we will have to affirm, similar to a postulate, the existence of a law which is anterior and superior to the state" (s.n.) $)^{7}$. It is what the Constitution of Romania, after the 2003 revision, also does, once it transforms the ideals of the Revolution in formal norms of the positive constitutional system.

The second question regards the relations between the original and the derived constituent authority. Is there a hierarchical relation between the wills of the two types of authority? According to the answer to this question, material limits of the derived constituent authority, therefore material limits of the revision, may or may not be instituted by the original constituent authority. The first option indicates towards a hierarchy between the original and the derived constituent authority, a direct result of a revolutionary movement that institutes a new system, different from the one upset by

\footnotetext{
5 "Le Fédéraliste", no. 31, op. cit., p. 319.

${ }^{6}$ In the Genesis of the Constitution of Romania - 1991, The work of the Constituent Assembly, the Autonomous Office the Official Gazette, coordinating editor Dumitru Ioncică, Bucharest, 1998, p. 908.

${ }^{7}$ L. Duguit, Manuel de droit constitutionnel, E. de Bocard, Paris, 1918, p. 2.
}

STUDIES AND ARTICLES 


\section{Dan Claudiu DĂNIŞOR}

revolution, which tries to protect itself from the comeback of the old system through the limitation of the possibility of constitutional revision.

The fundamental idea is the constitutional provisions which cannot be revised to be chosen by reference to the system which has been denied through revolution, not to interdict a subsequent evolution of the system. For example, in this optic, the original constituent authority could have prohibited in Romania the revision of those features of the system which, if contrarily revised, could pave the way towards a regression into totalitarianism: political pluralism, separation of state and parties, separation of powers etc.

Nevertheless, the material limitation of the power of revision cannot be valid if it concerns constitutional provisions that are not tied to the negation of totalitarianism, as is the Republican form of government, due to the fact that, in Romania at least, there is no identification between the totalitarian dictatorship which the people had revolutionarily overcome and the monarchy. On the contrary, there could have been the idea that the function of president, instituted by the communist regime for the benefit of the dictator Nicolae Ceauşescu, is co-substantial with the revolutionarily overcome regime and should not have been reintroduced to system of constitutional bodies. An attempt to make such a connection existed in the period of the debates of the 1991 Constituent Assembly. Thus, Mr Constantin Sorescu affirmed: "The Romanian people opted for the form of government, specifically for the Republican form in the night of $21^{\text {st }}-22^{\text {nd }}$ December 1989 [...]. Ceauşescu's monarchic style and the perspective of establishing a dynasty deepened an older and general aversion of the Romanian society towards royalty, monarchy and dynasty" ${ }^{\text {. }}$

The problem is treated differently in the case of the option for the second type of answer to the above mentioned fundamental question. There can be no hierarchy of the will of the original constituent authority and of the derived of. What kind of superiority can the will of a body that is not the result of a vote, but that of a diffused movement which can be easily analysed as coup d'état have compared to a body established through procedurally valid manifestation of the political will of the electorate, as is the derived constituent authority? In the eyes of many, there is no superiority. Can we justifiably claim that the Council of the National Salvation Front was in revolutionary Romania closer to the will of the people, of the constituent power, than the Parliament elected by vote in 2003? From this point of view, the problem of the hierarchy between the wills of the two forms of constituent authority could be easily resolved in the favour of the constituent authority established according to the Constitution in force, i.e. to the authority that decides the revision. Let us remember the never-ending discussions about the validity of the 1990 elections in Romania that led to the establishment of the Constituent Assembly. Did such contestation still exist in 2003,

\footnotetext{
${ }^{8}$ In the Genesis of the Constitution of Romania - 1991, The work of the Constituent Assembly, the Autonomous Office the Official Gazette, coordinating editor Dumitru Ioncică, Bucharest, 1998, p. 907.
}

\section{CONSTITUTIONAL LAW REVIEW}


when the Constitution was revised? Obviously, they did not. Therefore, which Assembly has higher legitimacy? Quite probably, the answer in favour of the 2003 Assembly can be easily translated into the overturning of the well-established idea that the 1990-1991 Assembly should be able to materially limit the competence of the 2002 Assembly. From this perspective, the material limits of the power of revision cannot validly exist.

\section{§1. MATERIAL LIMITS}

The 1991 Romanian Constitution established certain material limits concerning the power of the derived constituent authority, i.e. concerning the revision. They are regulated by art. 152(1) and they regard "the national, independent, unitary and indivisible character of the Romanian State, the republican form of government, territorial integrity, the independence of justice, political pluralism and official language". The constitutional provisions that regulate these segments "shall not be subject to revision". They shall not be discussed. It is not a matter of imposing an end to revision, but of excluding the debate. The procedure is evidently undemocratic, because in a democracy everything can be, in principle, subject to debate. The stability of the state, a result of the stability of the Constitution, is opposed to democracy, which naturally manifests the tendency to upset the system. The material limits of the competence of revision are consequently limits of democracy. Therefore, they should be regarded with prudency.

How should these material limits be? A first idea has been mentioned above: they must result from the fundamental opposition between the new system created as a result of a revolution and the system overturned by the revolution. The option comes naturally, because the revolutionary people usually adopt a negative, not a positive stance. They deny a system, instead of clearly asking a certain system for the future.

Are the material limits imposed by the 1991 Constitution of Romania limits such as these? Some are. For instance, we can mention political pluralism and the independence of justice. But the other limits, provided for by art. 152(1) of the Constitution, do not verify this condition. The characteristics of the Romanian state established as material limits of the revision were not transposed in 1991 differently from communist constitutions and were, therefore, not created on the basis of the will of the revolutionary Romanian people to oppose the communist totalitarian dictatorship.

Obviously, these limits must be based on something else, in order to be validly introduced as limits of the democratic debate. One option would be the undisputed character of these issues. Thus, in a democracy the very rule of democracy is undisputed, according to which we only agree on the fact that we ought to peacefully resolve conflicts between us; otherwise everything can be debated. The state's 


\section{Dan Claudiu DĂNIŞOR}

democratic character, understood in this procedural manner, could be validly declared a material limit of the power of revision. It is what the Commission for the drafting of the Constitution of Romanian did in 1990-1991, as in the Theses of the Constitutional Draft the "democratic form of government" was provided as material limit of revision. It was later on replaced with the republic form through a debatable procedure that I will subsequently analyse.

A second provision that can be labelled undisputed in a modern liberal democracy refers to the national character of the state. If the nation is made up of citizens, i.e. from individuals who are detached from their primary identity affiliations when they exercise their political freedom - a freedom that represents the foundation of the state - the state can only be national. Surely nevertheless, such a liberal conception of the national, which implies its neutrality, is far from being undisputed in Romania. It was circulated during the 2003 debates for revision by Valeriu Stoica who affirmed on behalf of the liberal group that it "gives the 'nation' a civic sense, not an ethnic sense. Indeed, the 'nation' is first and foremost the 'nation of the citizens', not a 'nation of blood'. Today, more than ever, it is proof of political opacity for one to believe that there is still a nation founded on the purity of blood". (...) "Tolerance makes possible the union of these different collective identities in a civil nation understood as foundation of the Romanian state. If we transform the cultural differences between us, the linguistic difference in communication barriers, no political construction is any longer possible". Similarly obvious is that this vision is perceived by national minorities in Romania and by a significant part of the majority as a mask of the ethnic character of the Romanian state. The problem is, therefore, debatable. It does not achieve the consensus that democratic procedures create and cannot validly constitute itself in a limit of the power of revision, at least not if the material criteria are based on the idea of the indisputability of the values that it protects.

The independence of the Romanian state cannot be subject to a revision. This characteristic of the state is inherently related to its existence as state. Therefore, it can be imposed as material limit of the power of revision. It should be observed that this concerns only external sovereignty, which the Constitution of Romania differentiates from internal sovereignty, as provided for by art. 1 which stipulates that Romania is a "sovereign and independent" ${ }^{9}$ state.

Regarding the sovereignty of the state, "as its peremptory characteristic", the Constitutional Court "remarks that it is not subject to art. 148 (152 according to the new numbering, n.n.) of the Constitution which establishes the limits of the revision of the Constitution, but that subject to it is instead the independent character of the Romanian state. Independence is an inherent dimension of national sovereignty, even if

\footnotetext{
${ }^{9}$ Regarding the consequences of this distinction see also D.C. Dănișor, Constituția României comentată, Titlul I Principii generale [The Commented Constitution of Romania, Title I - General Principles], Universul Juridic Publishing House, 2009, pp. 27-29.
}

CONSTITUTIONAL LAW REVIEW 
it has stand-alone consecration in the Constitution. The independence takes into consideration the exterior dimension of national sovereignty, conferring the state full freedom of manifestation in international relations. From this point of view it is obvious that the adherence to the Euro-Atlantic structures will be made on the basis of the independent expression of the will of the Romanian state, since it is not about a manifestation of will imposed by an entity outside Romania. From this perspective, the Court considers that the introduction of the two new articles in the Constitution art. $145^{1}$ and $145^{2}$ - does not represent an infringement of the constitutional provisions concerning the limits of revision"10.

Therefore, Romania can be an independent state even if it limits its sovereignty, should the constituent authority decide so. In other words, powers resulting from internal sovereignty can be passed on to someone other than the state, but powers deriving from the independence of the state cannot be transferred. This differentiation between sovereignty and independence authorises the transfer of internal powers to an external body, as long as the state remains independent, i.e. as long as it decides the limits of its external power. This is the exact opposite of federalism, in which case the external competences of the federated state are transferred, in principle, to the federation. In case of Romania, only internal sovereignty can be limited, but not external sovereignty.

In reality nevertheless, even the concessions of internal powers have limits. Consequently, the material limit of the revision of the Constitution can be extensively interpreted. These concessions cannot refer to the constituent power, because this concession would involve the submittal of the determination of external competence, i.e. of independence, which is impossible to affect according to our Constitution. Furthermore, these concessions cannot refer to the general power of regulation, since they are only exceptional, punctual. Practically, the Constitution of Romania accepts the ratification of a treaty that would affect internal sovereignty, if it is not contrary to the Constitution, otherwise its revision being necessary. This is the reason for which the Constitutional Court claims that "in our times [...] the concept of national sovereignty can no longer be conceived as absolute and indivisible"11. But the Constitution does not accept a treaty that would impact adversely on external sovereignty, i.e. on the independence, not even when there is an authorisation given by the constituent power. It is why the independent character of the state cannot be subject to revision.

The owner of sovereignty and independence is the state. This means firstly that competences (powers according to art. 148 para 1), not sovereignty, can be transferred to an external body. The transfer cannot create a new sovereignty. The Constitutional Court is formal in this respect: "through the acts of transferring certain powers to the

\footnotetext{
${ }^{10}$ Decision no. 148/2003, Official Gazette no. 317 from 12.05.2003.

11 Ibidem.
} 


\section{Dan Claudiu DĂNIŞOR}

structures of the European Union, these powers do not obtain, through bestowal, a "supra-competence", a sovereignty of their own"12.

The integrity of the territory can also appear non-debatable. Its consequence would be its inalienability, which was defined by the Constitutional Court of Romania according to which the practices "of abandoning territories, of losing them by means of prescription, as well as transfers of territories"13 are incompatible with this principle. The essence of these interdictions is that the territory cannot be either totally or partially transferred to the sovereignty of another existing state or which would be established though this act or through the will of the derived constituent authority.

On the other hand, they cannot be considered as inherently undisputable, regardless of how much we stretch the concept, the unitary and indivisible character of the Romanian state, the republican form of government and the official language. This means that, in order for them to be validly introduced as material limit of the power of revision, they should be based on a fundamental idea other than the two analysed above. I must, nonetheless, admit that this idea eludes me. The only motivation could be historical one. Nevertheless, history, irrespective of its clarity, which is not always the case, cannot constitute on its own a reason for limiting the future evolution of a political community. In any case, the non-revisable character of the provision that imposes Romanian as the official language is far from being founded on an indisputable tradition of the Romanian people. Thus, the Constitutional Court has justified the constitutionality of introducing by law the right of minorities to use their mother tongue in the relations with the local public administrations exactly through the existence of a "long democratic tradition regarding the use of the mother tongue in the relations between the citizens who belong to a national minority, with a certain weight in the ensemble of the population, and the local public authorities"14.

The unitary and indivisible character of the Romanian state can have historical significance for the Romanian people, considering the way in which it has been established, but this fact on its own cannot justify blocking any possibility of debate about federalism. For example, what would happen if the Republic of Moldavia decided the union with Romania on the condition of adopting a federal system, such as it had already occurred before the Great Union, at least in a first stage? Will we refuse the union because we cannot revise the unitary character of the state? Consequently, this is not matter of the current option (the Romanian state can be validly declared unitary and indivisible), but of blocking any different option for the future, regardless of the circumstances. However, it is obvious that, under certain circumstances, it would be better for this option to remain open.

\footnotetext{
12 Decision no. 148/2003, Official Gazette no. 317 from 12.05.2003.

${ }^{13}$ Decision no. 73/1997, Official Gazette no. 75 from 29.04.1997.

${ }^{14}$ Decision no. 112/2001, Official Gazette no. 280 from 30.05. 2001.
} 


\section{Critical considerations regarding the limits of the power...}

In conclusion, it is clear that some of the material limits of the power of revision introduced by art. 152 of the 1991 Constitution do not meet any of the conditions necessary to such a limitation. They have been introduced circumstantially and can have perverse effects on the way in which the Romanian society evolves. Their principled validity is, therefore, debatable.

In case of the republican form of government the formal validity of the limit can also be discussed, due to the manner of adopting the norm. The theses submitted for debate to the Constituent Assembly during the meeting held on May $15^{\text {th }} 1991$ contained the following formulation of the material limits of the power of revision: "The provisions of the present Constitution with concern to [...] the democratic form of government shall not be subject to revision"15. Not even one word about the republic. The amendment of the Member of Parliament Mr Gavra, voted by the Constituent Assembly, contained the same formulation concerning the form of government ${ }^{16}$, even if it was otherwise different from the proposal of the Commission. The text adopted by the Assembly consequently imposed the democratic form of government as material limit of the revision, which was in conformity with the first, above analysed, criterion of validation of this type of limit: the opposition against the totalitarian dictatorship of the revolutionary constituent power. The Commission was restricted by the vote of the Assembly. It could not change the Theses after they had already been voted.

Nevertheless, in the Constitutional Draft the text is different from the one that the Assembly voted and the limit invalidly transforms into the interdiction of the revision of the "republican form of government". This time, the revolutionary constituent power that opposed the revolutionarily overturned regime can no longer be invoked, due to the fact that the republic was introduced in Romania by the communists. History cannot equally be invoked, due to the fact that Romania had had a well-contoured monarchic tradition, not a republican tradition. Nor the indisputable nature of the republican form can be invoked, because it clearly results from the debates of the Assembly that this limit of revision has been one of the most contested.

The option for the interdiction of the revision of the republican form of government crept into the debate of the 1991 Constituent Assembly. Mr Antonie lorgovan recognised this fact during the debates concerning an amendment that targeted the elimination of this limit. He affirmed: "The love of truth obliges us to draw the attention of the Constituent Assembly to the following aspect: in the adjudicated thesis there were no expressions as 'republican form of government'; the expression 'democratic form of government' appeared instead. The forms of government - I do not want to go into detail - are clear: we speak either of republic or of monarchy"17. $\mathrm{Mr}$

\footnotetext{
15 The Theses of the Constitutional Draft, Title V - The Revision of the Constitution, which became the Constitutional Draft Title VI, In the Genesis of the Constitution of Romania - 1991, The work of the Constituent Assembly, the Autonomous Office the Official Gazette, coordinating editor D. Ioncică, Bucharest, 1998, p. 899.

${ }^{16}$ In the Genesis of the Constitution of Romania - 1991, op. cit., p. 900.

${ }^{17}$ In the Genesis of the Constitution of Romania - 1991, The work of the Constituent Assembly, the Autonomous Office the Official Gazette, coordinating editor D. Ioncică, Bucharest, 1998, p. 906.
} 


\section{Dan Claudiu DĂNIŞOR}

lorgovan uses euphemisms to mask the truth: the thesis had not been "adjudicated", but adopted by the Assembly, and the Commission could not introduce it to the draft. On the other hand, Mr lorgovan could have been more specific: the form of government can be classified in a different way other than by reference to manner of the establishment of the Head of state; moreover, the institution of the Head of state can be absent from the constitutional organisation of a state without any problems. Thus, the form of government can be either democratic or autocratic, either liberal or totalitarian. The revolutionary people had opted on its own for liberal democracy, because this was the only available option against the totalitarian autocracy, but it had opted neither for the republic in disfavour of the monarchy, nor for the existence of a Head of state, regardless of manner if its establishment.

Yet again the debates concentrated on the option of the Constituent for the form of government, not on the establishment of this form as material limit of the power of constitutional review. However, the two problems are radically different. The first problem shows the option of a political body for the present, while the second bans for all eternity the vote of the electorate in regard of this issue. There were parliamentarians who grasped the nuance, but the distinction was distorted by the recommencement of the issue of the momentary option. Thus, Mr Ion Diaconescu affirmed: "We, a Chamber - now Constituent - cannot with a certain majority decide for eternity what the form of government should be. Therefore, let us leave the possibility of revision to future parliaments as well [...]. [...] it was well the way it was - 'the democratic form' - because democracy is a principle that no one denies, but the form of government can change. We do not require the Constitution to stipulate: 'the form of government is the monarchy'. It was written 'republic', but the possibility to revise must be provided for ${ }^{\prime 18}$. The fact that a referendum followed for the approval of the Constitution could not, in the eyes of some of the parliamentarians in 1991, justify the material limitation of the power of revision. Thus, Mr Sorin-Mircea Bottez said: "I wanted to underline the fact that there are attempts to launch an affirmation which finds no basis, namely that a referendum is definitive. The role of the referendum [...] is precisely to express a people's changes of opinion"19.

The Constituent Assembly voted the text of the Commission and consequently introduced the republican form of government as material limit of the revision. Nevertheless, this was made without compliance with the procedures of the Constituent Assembly, as they were approved in its Regulation ${ }^{20}$. Formally therefore, the limit was not validly introduced, even if obtained the majority in the Assembly. The consequences of this fact could be decisive.

The efficiency of the constitutional provisions that impose material limits of the power of revision has been often questioned. Those who oppose this type of limits have

\footnotetext{
${ }^{18}$ In the Genesis of the Constitution of Romania - 1991, The work of the Constituent Assembly, the Autonomous Office the Official Gazette, coordinating editor D. Ioncică, Bucharest, 1998, p. 906.

19 Ibidem, p. 908.

20 The Constituent Assembly, Decision no. 1/1990 and Decision no. 1/1991.
} 


\section{Critical considerations regarding the limits of the power...}

developed the theory of the double revision: firstly the provision that limits the revision is revised, then a second revision is initiated, which applies to those provisions whose revision had been initially interdicted. In the process of establishing the material limits of the revision from art. 152 of the Constitution of Romania this issue was raised, but echoed insignificantly. Thus, Mr Károly Ferencz Szabó affirmed: “For article 147 (152 according to the current numbering n.n.) to become operational, it should first contain the following sentence: "The revision of article 147 as well"21. Most contemporary Romanian doctrinarians oppose the idea of the double revision ${ }^{22}$, but this does not mean that in the future politicians will not be able to appeal to it and the Constitutional Court will not be able to admit it. The alternative could be the blockage of the system because of its own internal logic and the opening of the revolutionary paths of change. The reality does not always wait for law to catch up with it. It can withdraw the legitimation of the constitutional system. In the absence of legitimation legal systems have no intrinsic value.

\section{§2. TELEOLOGICAL LIMITS}

The 1991 Constitution of Romania also establishes teleological limitations of the power of review. The Constitution cannot be revised if a certain result is achieved through it. The assessment of the probability of this result raises, nevertheless, several sensitive interpretation issues. But firstly let us see if such a limitation is valid.

This time, it is not about the indication of the constitutional provisions that cannot be subject to the revision, but about the establishment of an undesired result of the procedure. The finality of the revision must be judged in relation to the finality of the system. Can the constituent authority at one time determine for eternity what this finality is? In a modern liberal democracy the scope of the constitutional system is freedom. I have analysed extensively in another paper the way in which this type of social scope is established in the modern epoch and, at the same time, the fact that it is historically and culturally determined ${ }^{23}$. In modern liberal democracies the scope of the social system and, therefore, of the constitutional system is the promotion and guarantee of the freedoms and rights of the people. In this legal and cultural space no constitutional revision can result in the suppression of the fundamental rights and

\footnotetext{
${ }^{21}$ In the Genesis of the Constitution of Romania - 1991, The work of the Constituent Assembly, the Autonomous Office the Official Gazette, coordinating editor D. Ioncică, Bucharest, 1998, p. 908.

${ }^{22}$ See also E.S. Tănăsescu, Comentariul art. 150 din Constituție [Commentary regarding Article 50 of the Constitution], in I. Muraru, E.S. Tănăsescu (coord.), C.H. Beck Publishing House, Bucharest, 2008, pp. 1458-1459.

${ }^{23}$ D.C. Dănişor, Modernitate, liberalism şi drepturile omului. Drept constituțional şi instituţii politice [Modernity, Liberalism and Human Rights. Constitutional Law and Political Institutions] - vol. I, Simbol Publishing House, Craiova, 2017.
} 


\section{Dan Claudiu DĂNIŞOR}

freedoms of the people or of the means through which they are guaranteed ${ }^{24}$. The validity of such a limitation of the powers of revision is, consequently, indisputable if we are in liberal modernity. All pretences of universality considered, this limitation is nevertheless historically circumscribed. But the magnitude of the social change that could make it questionable is particularly substantial. It is a matter of changing the political regime, but of changing the society. Totalitarianisms were such changes. It was about changing the scope of society: not the man, but social totality was the scope under totalitarianism.

Anti-communist revolutions targeted the overturn of this scope, in view of which both the political community and the society as a whole was established. The people no longer wanted the rights and freedoms of each individual to be sacrificed on behalf of a transcendent good, of an ideal society, made up of new people, also ideal, radically different from the ones who live in the "here" and the "now". Anti-communist revolutions were made on behalf of the present, not some idealised future. The present time and space rights and freedoms were preserved through the limitation of the power of society itself to suppress them for achieving some future, supposedly better for all people, but also through the sacrifice of each individual's concrete life. If the interdiction of the revision of a form of political organisation represents its refuse to commit suicide ${ }^{25}$, the interdiction of the revision that would result in the suppression of the rights, freedoms or their guarantees represents the refuse of the people to be crushed by society on behalf of the common good.

The suppression of the rights or freedoms guaranteed by justice cannot be subject to political negotiation, regardless of how overwhelming the parliamentary majority that adopts the regulation may be, just as in John Rawls' philosophy ${ }^{26}$. On the other hand, the fundamental rights and freedoms are inalienable, which means that not even the individuals, either alone or reunited within the electoral body, through the exercise of the right to vote, can waive them. The calculus of social utility and, therefore, the referendum cannot concern the suppression of the rights, the freedoms or their guarantees.

The second problem refers to the way in which this prohibited potential result of the revision should be assessed. Firstly, what is the referent of control? The temptation to say that we must make reference to the provisions of the Constitution that is in force at the moment of the analysis is very high. In Romania it is uphold by the fact that the prevalent doctrine defines the fundamental character of the rights and freedoms in

\footnotetext{
${ }^{24}$ For a systemic overview of the issue see Wagdi Sabète, Pouvoir de révision constitutionnelle et droits fondamentaux. Etude des fondements épistémologiques, constitutionnels et européens de la limite matérielle du pouvoir constituant dérivé, Presses Universitaires de Rennes, 2005.

${ }^{25}$ P. Charlot, L'article 111: l'impossible révision ou le refus du suicide de la République?, in La Constitution du 4 novembre 1848: l'ambition d'une république démocratique, Editions Universitaires de Dijon, 2000, pp. 315-331.

26 "In a just society, (...) the rights guaranteed by justice shall be subject neither to political negotiation, nor to social interests" (J. Rawls, Théorie de la justice, Paris, Seuil, 1987, p. 30).
} 
relation to their provision in the Constitution. As previously underlines, a right or a freedom are not fundamental because they are provided for in the Constitution, but must be provided for in the Constitution because they are fundamental ${ }^{27}$. Their fundamentality is construed outside the frame of state law. If a constituent at a certain time has forgotten to provide in the Constitution a right or a freedom, it does not mean that they are no longer fundamental. This is also the view shared by the Constitutional Court of Romania, as it jurisprudentially constitutionalises rights that are provided for neither in the 1991 Constitution, nor in the 2003 Revision Law: the law to difference ${ }^{28}$, the right to one's own image ${ }^{29}$, contractual freedom ${ }^{30}$ etc.

If we adopt such a criterion of defining fundamental rights and freedoms, the sphere of reference concerning the limit of the power of power extends: concerned are all rights and freedoms that constitute normative principles which are materially constitutional, i.e. are secondary norms that therefore regulate the way in which the state shall regulate the conduct of its subjects. For instance, contractual freedom represents such a norm, as it imposes a certain limit of the way in which the state can regulate the conduct of the subjects in contractual matters. It is fundamental even if it is not provided for in the Constitution. Therefore, this freedom is a material limit of revision. Not even the constituent authority or the referendary people can suppress the people's freedom to contract. The teleological limit of the revision of the Constitution therefore concerns the material Constitution, not only the formal one. It must be extended to all rights or freedoms which are fundamental in the material sense explained above, not only to those expressly mentioned in the Constitution in force. Similar to the ones already constitutionalised by the Constitutional Court are, for instance, the right to pluralism which would thus complete the material limits provide for in art. 152(1) of the Constitution that makes reference only to political pluralism. This right results in the Romanian system from the text of art. 8(1) which makes of pluralism a 'guarantee'. It is not about an enforcement of the fact that in the absence of pluralism there is no democracy, but about a right awarded to the citizens to claim pluralism. The guarantee is awarded to the citizens, not to democracy. This means that,

\footnotetext{
${ }^{27}$ See also D.C. Dănişor, Exercițiul drepturilor şi libertăților - între liberalism și etatism [The Exercise of Rights and Freedoms - Between Liberalism and Statism], Public Law Review no. 3/2017, pp. 20-35.

28 "The principle of equality does not mean uniformity, so that, if to equal situations an equal treatment must correspond, in different situations the legal treatment cannot be but different [...]. The infringement of the principle of equality and non-discrimination exists only when a differentiated treatment is applied to equal cases, in the absence of an objective and reasonable motivation or if there is a disproportion between the aim pursued by unequal treatment and the means used. Real inequality, which results from the difference of situation may justify distinct rules, depending on the scope of the law. it is why the principle of equality leads to the underlining of a fundamental right, i.e. the right to difference, and in as far as equality is not natural, imposing it constitutes a discrimination" (Decision of the Constitutional Court of Romania no. 107/1995, Official Gazette no. 85 from 26.04.1996).

${ }^{29}$ Decision no. 54/2000, Official Gazette no. 310 from 5.07.2000.

${ }^{30}$ On hesitations of the Constitutional Court of Romania in the field of the constitutionalisation of contractual freedoms see E.M. Nica, Libertatea contractuală în dreptul public şi privat, român şi francez [Contractual Freedom in Romanian and French, Public and Private Law], doctoral thesis, Craiova, 2008.
} 


\section{Dan Claudiu DĂNIŞOR}

on the basis of art. 8, citizens can refer the matter to the Constitutional Court, so that the latter may impose pluralism on potential abuses of the legislative power, even if no other fundamental right comes in directly. Article 8 of the Constitution therefore guarantees a distinct fundamental right: a right to pluralism. Of course, this right is linked to the freedom of association, but is not confused with it. For instance, economic pluralism does not necessarily presuppose the right to association. One single person, as natural person, may invoke the infringement of economic pluralism, if they wish to become trader and the law unjustifiably restricts this right ${ }^{31}$.

A further essential aspect refers to what is understood by the suppression of a right or freedom. Of course, the prohibition firstly presupposes the interdiction of the revisions that would eliminate from the Constitution the provision that regulates the respective right or freedom. The constitutional catalogue of rights can only expand and never become narrower. An express elimination of a right or a freedom from the Constitution through an act of the derived constituent authority is not very likely, at least not as long as the state remains a liberal democracy. Therefore, the limit of revision must take into account an indirect effect as well. Through an apparently neutral revision an effect equivalent to the suppression of the right or freedom should not be able to be obtained.

The Constitutional Court of Romania indirectly ruled on this issue. Thus, by deciding with regard to the restriction of the freedom of association in parties established by the laws that had regulated until the Decision of the Constitutional Court of Romania no. $75 / 2015^{32}$, the Court held that "the assessment of the opportunity of a certain threshold of representativeness is not [...] a problem of constitutionality, as long as the established threshold does not result in the suppression of the exercise of the right. [...] This criterion may be considered unconstitutional, if, through its effects, it would lead to the suppression of the right to association or would be synonymous with such suppression" $^{\prime 3}$ (s.n.). The Court took view of the rise in the minimum number of members so much that it could deprive the right to free association of its substance. By extrapolating, any restriction of the exercise of the right that infringes, through its extension or intensity, the substance of that right or freedom, or whose effects would lead to such suppression or would be equivalent with it, cannot be subject to a valid revision.

What do we understand through the substance of a right or freedom? In my opinion, it is about the structural elements that are necessary to its existence. We

\footnotetext{
31 D.C. Dănișor, Constituția României comentată [The Commented Constitution of Romania], op. cit., pp. 267-268.

32 Published in the Official Gazette no. 265 from 21.04.2015.

${ }^{33}$ Decision no. 35/1996, Official Gazette no. 75 from 11.04.1996. The arguments are reiterated in the contents of Decision no. 147 from 27.10.1998, published in the Official Gazette of Romania, Part I, no. 85 from 01.03.1999, which concerns the same provisions of art.17 para (1) letter b) of Law no. 27/1996, as well as subsequently in Decision no. 433 from 25.05.2006, published in the Official Gazette of Romania, Part I, no. 492 from 07.06.2006, and Decision no. 954 from 06.07.2010, published in the Official Gazette of Romania, Part I, no. 551 din 05.08 .2010 , both concerning the provisions of art. 19 para (3) of Law no. 14/2003.
} 
speak, therefore, of the subject of the right or freedom, of their object and their inherent legal relation. The guarantee of the right, the fourth structural element of the fundamental rights or freedoms, is treated by the Constitution of Romania as a distinct limit of revision. I will also treat it separately.

A limit of revision would hence be any change in the nature of the subjects who benefit from a right or a freedom, through which the existence of the right or freedom is jeopardised. To remain within the boundaries of the example from the jurisprudence of the Constitutional Court, the freedoms of association belongs to the individuals. It is exercised collectively, but it does not belong to the collectivity. The transformation of the nature of the subject of law by imposing the necessity of converging the wills of an excessive number of subjects in order for the individuals to be able to exercise their freedom makes an essential element of the law to become inoperative for its bearers who are part of a minority political group. It is, in the last analysis, the reason for which the Constitutional Court declared as unconstitutional the Law of political parties (no. 14/2003) through Decision no. 75 from 2015, in which the court held that the restriction of the right to association in parties through the imposition of the numerical condition and of territorial dispersion through the Law of parties "is not necessary in a democratic society" ${ }^{34}$. This is not about the discrimination of subjects in relation to others. It is simply about the transformation of the subject's nature. Like in the case of a change in the nature of the finality of the system when there is a crossover from a liberal state (whose end purpose is the individual) to a totalitarian state (whose end purpose is the social group as a whole), the subject of the association is no longer the individual, but a numerically and ideologically representative group. The condition of representativeness of the group that could have constituted a party was not for the Constitutional Court of Romania, until the Decision of 2015, a matter of constitutionality, because the Court still thought that the finality of the system is society, its well-being, even if this society had succeeded in replacing the circumstantial finality: democracy had substituted itself for communism as systemic finality. Thus, the excessive pluralism resulting from the freedom of association, (too) open to all, was considered a fatality for democracy. The right to association in parties was not individual, but belonged to a qualified group that had to be a priori representative, not as a result of the citizens' vote. Such a metamorphosis of the subject of the law ought to not even be possible through the revision of the Constitution.

The substance of the fundamental right or freedom refers secondly to their object. However, what is understood by a revision that results in the affectation of the object of the law in such a way as to amount to its suppression? If we continue to refer to the right to free association in political parties, we see that its object is defined in art. 8 of the Constitution of Romania as contributing to "the definition and expression of the political will of the citizens" under the conditions of pluralism which is a "guarantee of

${ }^{34}$ Decision no. 75/2015, published in the Official Gazette no. 265 from 21.04.2015.

STUDIES AND ARTICLES 


\section{Dan Claudiu DĂNIŞOR}

constitutional democracy". Let us follow the reasoning of the Constitutional Court of which led to the declaration as unconstitutional of the legal norm that imposed the minim number of members and their territorial dispersion: "the Courts holds [...] that the provisions of art. 19 para (3) of Law no. 14/2003 regulate a measure which [...] no longer corresponds to the requirements [...] of necessity and that, through its excessive character, this leads to the impossibility of effective exercise of the right to association, which amounts to the affectation of the right in its substance" (s.n.). For the Court the substance of the right is equivalent to its effective exercise. The elimination of "the real and effective possibility of exercising the right" (s.n.) is equivalent to the suppression of the substance of the right. A state measure is, therefore, equivalent to the suppression of the right of the object of the right is no longer real and effective.

To follow up on the example of the freedom of association, it must be underlined that for several years the Constitutional Court affirmed that the tempering of pluralism can lead to the valid restriction of the right to association in parties. Now the Court holds that this guarantee of democracy cannot constitute through itself a reason for the restriction of the right. The functioning of the system is at last subordinated to the protection of the rights and freedoms of the people. By way of generalisation, a right or a freedom is not real and effective if it is simply positioned counter the general interest and the functioning of the system. This is the transposition of Jon Rawls' idea according to which "a basic freedom cannot be limited or denied, unless it protects one or more other basic freedoms and never [...] on behalf of public good or perfectionist values" 35 .

The legal relation inherent to the fundamental right or freedom is established between the owner and debtor of the obligation to respect the prerogative inherent to the right or freedom. This is firstly the state. From this point of view, the fundamental rights imply the constraint of the state to legislate or the limitation of the law-making act made by the state to what is necessary to the exercise of the right or freedom. Therefore, rights and freedoms are fundamental (and not only subjective) if they constitute limits of the state legislative framing of conduct. They are thus normative, but their object of law-making is represented by the limits of law-making, not by the conduct. They are constitutional in this way.

This legal relation cannot be suppressed through the revision of the Constitution. If the revision results in the suppression of the character of the fundamental right or freedom as limit of the way in which the state can regulate the conduct of its subjects, it lacks validity because it infringes the limit established by art. 152(2) of the Constitution. The transformation of the repressive regime of exercising the rights in a preventive regime is not open, under any conditions, even to the derived constituent authority.

In case of the rights from the second generation, the legal relation implies an action, not a constraint, from the debtor of the obligation. Therefore, the state must usually actively promote politics that can ensure the effective character of the

${ }^{35}$ J. Rawls, Libéralisme politique, PUF, Quadrige, Paris, 2007, p. 351.

\section{CONSTITUTIONAL LAW REVIEW}




\section{Critical considerations regarding the limits of the power...}

prerogative inherent to the fundamental right or freedom from the second generation. But the process of making law effective must not transform into the request of state activism in the state assistance for the exercise of the right. In the Romanian legal system a paternalist regime of exercising rights from the second generation can be established neither through acts of the legislative power, nor through the revision of the Constitution.

The second thesis of art. 152(2) of the Constitution of Romania establishes as teleological limit of the revision the guarantees of the fundamental rights and freedoms. No revision can be made if its effect is their suppression. As in the case of the limit analysed above, the first interdiction concerns the pure and simple suppression of the guarantee through its elimination from the Constitution. Examples could be the elimination of the Constitutional Court from the institutional system or the elimination of the constitutional provision concerning free access to justice. The issue at hand is the determination of these guarantees of the fundamental rights and freedoms.

The guarantees can be firstly regarded organically. Certain bodies have powers in the area of the guarantee of fundamental rights and freedoms. They cannot be eliminated from the system of state bodies if the means of guarantee are not transferred to another body that offers at least the same functional guarantees. Which are these bodies according to the Constitution of Romanian? We obviously speak of the Constitutional Court, the judiciary courts, the Public Ministry and the national ombudsman, because the Constitution expressly confers them this role. Other bodies can be thus qualified through the systemic and the teleological interpretation of the Constitution. An example is the Superior Council of the Magistracy which, by guaranteeing the independence of justice, indirectly guarantees the rights and freedoms protected by it.

The guarantees of the fundamental rights and freedoms can also be looked at from a functional point of view. The teleological limit of the revision of the Constitution is established from this perspective counter the attempts to use the derived constituent authority to divert the functions of the state from their finality, through indirect methods. The indirect method of suppressing the guarantees of the fundamental rights and freedoms means that the effect of an apparently neutral constitutional revision is equivalent to the suppression of the substance of the guarantee of the right or freedom.

This method may mean not the suppression, but the multiplication of the state structures involved in the process of guaranteeing the rights and freedoms. As in the case of the norms, the multiplication of structures, the organic inflation, equivalent to the normative inflation, is not a structuring, but a destructuring reaction, because the functioning of the structures becomes hard to understand for the subjects of law, the latter being incapable of using them for the purpose of defending their rights and freedoms. A destructuring through multiplication ${ }^{36}$. The 1923 Romanian constituents

\footnotetext{
${ }^{36}$ For more, see D.C. Dănișor, Democrația deconstituționalizată [Deconstitutionalised Democracy], Universul Juridic Publishing House, Bucharest, Universitaria Publishing House, Craiova, 2013, especially pp. 53-60. Part of the text will be reproduced in what follows.
}

STUDIES AND ARTICLES 


\section{Dan Claudiu DĂNIŞOR}

had intuited well this type of use of multiplication and specialisation. I think this is one of the reasons for which it had been stipulated that "special authorities of any kind, with attributions of administrative disputes, cannot be established" ${ }^{37}$. Today, a reverse reaction is the unprecedented multiplication of autonomous administrative authorities, including those with jurisdictional attributions ${ }^{38}$.

Another indirect method of suppressing the substance of guaranteeing the rights or freedoms is the de-institutionalisation of public functions that lead to their guarantee. For instance, such an effect can be obtained in case of justice through the continuous change of the structures in a kind of "permanent revolution" 39 . The permanent revolutionising of justice has embraced at least three forms in post-communist Romania: the multiplication of structures with parallel powers, the preservation of a reduced number of magistrates with extremely loaded attributions and the permanent change of the legal system which the courts and the prosecution services have to apply.

Finally, the revision can have the effect of suppressing the guarantees of the rights and freedoms if it affects one of the fundamental elements that provide a body or a system of bodies the effective possibility to guarantee the rights and freedoms. It is the case of the independence of justice which is stipulated as material limit of the power of the revision of the Constitution of Romania. An attempt to indirectly suppress the guarantees of the rights and freedoms this way was the reformation of the Superior Council of the Magistracy proposed through the initiative of revising the Constitution of Romania in 2011. This attempt failed due to the decision of the Constitutional Court ${ }^{40}$. The draft law of revision proposed a restructuring of the Council through which the judges would have become a minority within its frame, being dominated by the politically appointed representatives of the civil society and the prosecutors, subordinated to the ministry of justice and hierarchically within the frame of the system of the public ministry"1. But the Council is the "guarantee of the independence of

\footnotetext{
37 Art. 107 of the 1923 Constitution.

${ }^{38}$ See D.C. Dănişor, Expertul sau poporul? - Despre justificarea autorităților autonome [The Expert or the People? - On the Justification of Autonomous Authorities], in Revue des Sciences Politiques no. 1/2018, to be published.

${ }^{39}$ For an explanation of this mechanism see H. Arendt, Le système totalitaire, Seuil, Paris, 1962 and Originile totalitarismului [The Origins of Totalitarianism], Humanitas Publishing House, Bucharest, 1994.

40 The Decision of the Constitutional Court no. 799, from 17.06.2011, with reference to the Draft Law amending the Constitution of Romania, published in the Official Gazette no. 440 from 23.06.2011, see my commentaries the Romanian Pandects no. 6 and 7/2011.

41 Point 50. Paragraphs (2), (3), (4), (5) şi (6) of article 133 are thus amended:

Letter a) of paragraph (2) shall stipulate the following:

“a) 10 are elected in the general assemblies of the magistrates and validated by the Parliament; they are part of two sections, one for judges and one for prosecutors; the first section is made up of five judges and the second on eof five prosecutors;"

Letter b) of paragraph (2) shall stipulate the following:

"b) six representatives of civil society who enjoy high professional and moral reputation: three appointed by the Parliament and three by the President of Romania;"
} 


\section{Critical considerations regarding the limits of the power...}

justice" 42 . The reform was hence equivalent to its suppression, consequently to that of a guarantee of the rights and freedoms.

The suppression of the competences that help the guarantee of rights and freedoms, or the affectation of their substance can be made only by means of revision. One example is the a posteriori elimination of the power of constitutional control from the competence of the Constitutional Court. But the affectation of its substance by means of imposing an excessive filtration of the referrals would be equivalent to a prohibition of free access to the court of constitutional disputes. The removal of administrative disputes from the competence of the judiciary courts would be equivalent to an affectation of the guarantees of the rights and freedoms or the imposition of taxes would be equivalent to the impossibility of access to them.

I saw that the interpretation of the attributions of the Constitutional Court in a way that confers it a kind of masked constituent authority is possible ${ }^{43}$. Likewise, the attribution of resolving constitutional legal conflicts undergoes a similar process ${ }^{44}$. The Court can, therefore, indirectly obtain a revision of the Constitution, not in the way of amending certain express provisions, but in that of filling in the lacunae of the constitutional system. This possibility can only be used to enhance the protection of the rights and not to indirectly obtain a suppression of rights and freedoms or their guarantees. The Constitutional Court has this tendency sometimes. It is, for instance, the case when it restrictively interprets the sphere of the protection or the sphere of the subjects who benefit from the protection of art. 53 from the Constitution. Thus, it decided that if the restriction of the exercise of the fundamental law is based on a [...] special constitutional provision, i.e. the provision of art. 44 para (1), second thesis, the "compliance with the provisions stipulated by art. 53 of the fundamental law" 45 is no longer necessary. But, the protective provisions should be interpreted in favour of the individual and for the drastic limitation of the powers of the state to limit their rights and freedoms, so the requests of art. 53 and of the other provisions that limit the state should be fulfilled cumulatively. The Court obtains a revision of the Constitution through interpretation, which amounts to the suppression, in case of certain rights, of some of the constitutional guarantees. This type of jurisprudence is forbidden by art 152(2) of the Constitution of Romania.

In the same manner, the Court obtains an implicit revision of the Constitution, forbidden by the teleological limit imposed by art. 152(2) when it restricts the sphere of

\footnotetext{
${ }^{42}$ Art. 133(1).

${ }^{43}$ D.C. Dănișor, Lacunele dreptului - problemă structurală a sistemului juridic sau carență în protecția drepturilor? [The Lacunae of Law - A Structural Problem of the Legal System or a Gap in the Protection of the Rights?], Romanian Pandects no. 1/2016, pp. 21-29.

${ }^{44}$ Şt. Deaconu, Conflictele juridice de natură constituțională dintre autoritatea judecătorească și celelalte autorități publice în jurisprudența Curții Constituţionale a României [Constitutional Legal Conflicts between the Judiciary Authority and the Other Public Authorities in the Jurisprudence of the Constitutional Court of Romania], The Annals of the University of Bucharest - Law, 2011 - II, p. 233.

45 Decision no. 923/2006, Official Gazette no. 50 from 23.01.2007.
} 


\section{Dan Claudiu DĂNIŞOR}

the rights and freedoms protected by art. 53 on fundamental rights, and them on those expressly stipulated by the Constitution, even though the constitutional text refers to rights and freedoms in general, without mentioning them as being fundamental. Thus, the Court holds that "the text of art. 49 (currently 53, n.n.) does not refer to the restriction of the width or to the suppression of certain rights [...], but to the restriction of the exercise of certain existing rights, recognised by other constitutional texts; and in terms of the rights to which is concretely refers, objection is not among those enumerated under chapter II of title II of the Constitution" ${ }^{46}$. When it considers, through a restrictive interpretation that only citizens benefit from the constitutional protection of art. 53, it holds the following: "with regard to the infringement [...] of the provisions of art. 49 (now art. 53 - n.n.) of the Constitution [...], they do not fall under its scope because they make reference to the restriction of the exercise of certain fundamental rights or freedoms of the citizens, not to those of some commercial societies" ${ }^{\prime 4}$.

\section{§3. LIMITATION IN EXCEPTIONAL SITUATIONS}

Paragraph (3) of art. 152 of the Constitution of Romania provides that: "The Constitution shall not be revised during a state of siege or emergency, or in wartime". Such a limitation is natural. The Constitution should not be changed when the expression of the will of constituent power and that of the constituent authority can be altered by an exceptional state. The problem is that, in case of the Constitution of Romania, these states are very vaguely regulated by constitutional provisions, which leave too many degrees of latitude to the established powers.

Thus, the Constitution regulates neither the limits, nor the consequences of the states of siege and emergency, being solely preoccupied with certain procedural aspects which, although representing implicit guarantees of the limitation of powers, are insufficient in my opinion. The institutions are regulated by art. 93 that stipulates the following: (1) The President of Romania shall, according to the law, institute the state of siege or state of emergency in the entire country or in some territorial-administrative units, and ask for the Parliament's approval for the measure adopted, within 5 days of the date of taking it, at the latest. (2) If Parliament does not sit in a session, it shall be convened de jure within 48 hours of the institution of the state of siege or emergency, and shall function throughout this state". Article 73(3)g provides that "organic laws shall regulate [...] the state of siege and emergency". Art. 89(3) limits the possibility of dissolution, stipulating that "the Parliament cannot be dissolved during the last six months of the term of office of the President of Romania, or during a state of mobilization, war, siege, or emergency". What the Constitution does not regulate is the

\footnotetext{
${ }^{46}$ Decision no. 73/1995, Official Gazette no. 177 from 08.08.1995.

${ }^{47}$ Decision no. 104/2000, Official Gazette no. 383 from 16.08.2000.
} 
problem of the limits of the powers of the state over the subjects during these states. Only the interdiction of revision may seem as an extremely permissive limit.

Regarding the interdiction of revision in times of war, it is a problem that deserves several historical considerations. The 1866 Constitution of Romania was revised during the First World War through the Law amending articles 19, 57 şi $67^{48}$. This revision allowed the expropriation of the lands for the purposes of expanding rural properties and the extension of the right to vote. These two constitutional reforms have decisively contributed to a rise in the determination of Romanians to fight and have marked the fate of the war. The historical experience of Romania regarding the revision of the Constitution in time of war could, therefore, be interpreted to be positive. Nevertheless, if we consider the entry of Romania in the Second World War as the date of the ultimatum given by the Soviet Union through which the Romanian state was ordered to cede Bessarabia and Northern Bucovina, i.e. June $26^{\text {th }} 1940$, all the constitutional acts from September 1940, through which Ion Antonescu's dictatorship was established, represent revisions of the Constitution of Romania in time of war. From this perspective, these acts can no longer be interpreted as valid or beneficial. The interdiction of the revision of the 1991 Constitution of Romania in time of war is probably based on this last historical experience.

In conclusion, the limits of revision stipulated by art. 152 of the Constitution of Romania can be submitted to a critique of substance and validity. Not all of them are necessary, some are unclear, while others have been introduced in the Constitution through procedures that affect their validity. Nevertheless, the option of the Romanian constituents from 1990-1991 for the introduction of the three categories of limits of the power of revision has the merit of clarifying, at least in principle, the relations between the constituent power, the original and the derived constituent authority. The limitation of the latter is necessary. It now remains to be seen the way in which the 1991 constitutional work can be improved.

\footnotetext{
${ }^{48}$ Published in the Official Gazette no. 93 from 30.07.1917, see also C. Ionescu, Dezvoltarea constituțională $a$ României. Acte şi documente 1741-1991 [The Constitutional Development of Romania. Acts and Documents 1741-1991], $3^{\text {rd }}$ edition, C.H. Beck Publishing House, Bucharest, 2016, pp. 504-506.
} 